Koenig, C. I. (Paris).-Treatment of Singers' Nodes and other Excresceners of the Cords by Galvano-cauterisation; "A New Guarded Cautery." "Annales des Mal. de lOreille, du Tarynx, du Nez, et du Pharynx," November, 1910.

The author considers removal of singers' nodes and polypoid excrescences by the galvano-cautery preferable to ablation by forceps or the double curette. By this method the amount of tissue removed can be more exactly gauged. Moreover, the sealing of the vessels and lymphatios does much to prevent post-operative infection. He works with a specially. constructed cautery-burner. The platinum is for the most part protecteif by a sheath of copper, but at one point projects through the sheath in thr form of a bead, which constitutes the cautery point. When the current is on this bright little sphere stands out prominently against the copper background under reflected light, greatly facilitating precision during operation.

H. Clayton For.

\title{
TRACHEA AND GSOPHAGUS.
}

Large (Secord H.).-Some of my Mishaps in Seventy-five Cases if Tracheo-bronchoscopy and CEsophagoscopy. "Taryngosope," November, 1910 , p. 1050.

Four fatal cases are reported:

(1) Child, aged eighteen months, inhaled the kernel of a pea-nut. Owing to delay the patient was in extremis before any attempt was made to remove the foreign body. Removal was rapidly and successfully accomplished, but the child died.

(2) Child, aged two. Diagnosis of foreign body in the bronchus: made from the physical signs in the chest. Upper bronchoscopy was tried and the foreign body seen, but it was too large to enter the tube. A low tracheotomy was then performed, and the foreign body, a bean, removed. The child was suffering from pneumonia at the time of the operation, and died some hours later. Like the first case the fatal issm" would have been avoided if the child had been seen earlier.

(3) An cesophageal case in an adult. The patient was only able to swallow liquids, and that with difficulty. Cancer was diagnosed, and the œsophagoscope was passed in order to obtain a specimen for examination. The piece of "growth" removed was found to consist of lung-tissue. The patient died twenty-four hours later. A post-mortem was not obtained. The author used no pressure in inserting the tube, and is unable to explain why he got lung-tissue, unless the carcinoma hat ulcerated through into the lung.

(4) Child, aged eighteen months, with a penny in the osophagus just below the cricoid. The author tried to pass the cesophagoscope, but the opening of the cesophagus was very tight and hyperæmic, and as he feared to use force the attempt was given up. (Esophagotomy was resolved upon, but the child died before the operation.

In cases of foreign body in children the author follows Jackson : rule of first attempting removal without any anæsthetic whatever, local or general. 'The article concludes with several valuable practical hints. 